\title{
ANALYSING WILDFIRE OCCURRENCE THROUGH A MIXED-METHOD APPROACH: A CASE STUDY FROM THE CROATIAN MEDITERRANEAN
}

\author{
Kristina Jajtić, Valentina Galijan, Ivana Žafran and Marin Cvitanović
}

With 8 figures and 5 tables

Received 16 Apil 2019 · Accepted 28 November 2019

\begin{abstract}
Summary: Processes such as littoralization, socio-economic restructuring and agricultural abandonment facilitate land cover changes in the Mediterranean, which then lead to an increased fire risk in the region. These processes are in part driven by people's values, beliefs and traditional knowledge, lending itself to both qualitative and quantitative research approaches. However, despite the importance of human factors in wildfire occurrence and the complexity of humanenvironmental relations, such studies so far have been almost exclusively quantitative. This research aims at analysing the drivers of wildfire occurrence in the Mediterranean region of Dalmatia, Croatia through mixed-method approach. Croatia has gone through rapid social and economic changes in the past 30 years which have affected livelihood strategies and landscape configuration. The study includes spatial and statistical analysis of a set of variables during two fire seasons (2011 and 2013), but in-depth interviews with fire-fighters and farmers in the region as well. The results show that grassland and shrubland (maquis) are one of the most important drivers of wildfire occurrence in the region, and that they can be seen as indicators of the process of agricultural abandonment. The research demonstrated differing opinions on the use of agricultural burning in preventing wildfires between farmers and fire-fighters, but a common view of wildfires posing a risk only to human life and material property, disregarding potential risk to ecosystem services.
\end{abstract}

Zusammenfassung: Prozesse wie Litoralisierung, sozioökonomischer Wandel und Aufgabe landwirtschaftlicher Nutzflächen tragen zu einer Veränderung der Bodenbedeckung im Mittelmeerraum bei und in der Folge auch zu einer Erhöhung des Brandrisikos in dieser Region. Diese Prozesse unterliegen zum Teil Werten, Überzeugungen und traditionellem Wissen und Handeln der Menschen und eignen sich daher u. a. für qualitative und quantitative sozialwissenschaftliche Forschungszugänge. Trotz der Bedeutung der menschlichen Faktoren für das Auftreten von Wildbränden und der Komplexität der Mensch-Umwelt-Beziehungen lag der Schwerpunkt bisheriger Studien vorzugsweise auf quantitativen Ansätzen. Ziel dieser Forschung ist es demgegenüber, die Ursachen für das Auftreten von Wildbränden im Mittelmeerraum Dalmatiens und Kroatiens durch einen gemischten Methodenansatz zu analysieren. Kroatien hat in den letzten 30 Jahren einen rasanten sozialen und wirtschaftlichen Wandel erlebt, der sich auf die Lebensgrundlagen und die Landschaftsgestaltung ausgewirkt hat. Die Studie beinhaltet räumliche und statistische Analysen einer Reihe von Variablen während zweier Brandzeiträume (2011 und 2013), aber auch vertiefende Interviews mit Feuerwehrleuten und Landwirten in der Region. Die Ergebnisse zeigen, dass Grasland und Strauchland (Macchie) die wichtigsten Quellen für das Auftreten von Lauffeuer in der Region sind und dass sie als Indikatoren für den Prozess des landwirtschaftlichen Wandels angesehen werden können. Anhand der Studie wird deutlich, dass die Bedeutung traditioneller Landnutzungspraktiken und Möglichkeiten der Brandverhütung von Landwirten und Feuerwehrleuten sehr unterschiedlichen bewertet werden. Einigkeit herrscht allerdings hinsichtlich der Einschätzung, dass die Brände vor allem ein Risiko für die Bevölkerung und materielles Eigentum darstellen; Aspekten wie Biodiversität und Ökosystemdienstleistungen wir dagegen keine Bedeutung beigemessen.

Keywords: Wildfires; landscape research; qualitative analysis; land cover change; agricultural population; Mediterranean

\section{Introduction}

Wildfires burn around 348 million hectares of land annually (GIGLIO et al. 2013). In Europe, the largest number of wildfires occurs in the Mediterranean, which is considered as one of the most fire-prone environments in the world (Turco et al. 2016). It is estimated that around 45000 wildfires occur in Mediterranean Europe every year, causing large eco- logical and socio-economic damage (Oliveira et al. 2012; Gudmundsson et al. 2014).

The causes of wildfires can be natural (drought, high temperatures, low air humidity, wind regime, lightning strike) or anthropogenic (burning of weeds on agricultural surfaces, unextinguished camping fires, and various ecological incidents) (MüLLER et al. 2013; Tsoi 2009; Costa Freitas et al. 2017). Around $95 \%$ of wildfires in the Mediterranean are caused by 
human factor: negligence, inadvertent and deliberate ignition (RosAVEc et al. 2012; VILlar et al. 2016). These wildfires are unpredictable but can be linked to both physical (e.g. temperature and precipitation) and socio-economic (e.g. agricultural activities and practices) characteristics of a region (GANTEAUME et al. 2013). Different types of land cover are also often linked to wildfires, such as coniferous forests or Mediterranean shrubland (maquis), which easily ignite even from a small heat source, especially during drought and harvest season (PICHLER 2008).

Data from the European Environment Agency (EEA) show that the wildfire frequency in five southern European countries (Portugal, Spain, France, Italy and Greece) increased during the 1990s, then stabilized for a decade, and then slightly decreased during the recent years. However, these data also show that wildfires are now affecting previously non-fire prone ecosystems as well. The study by Turco et al. (2016), encompassing the same five countries in the period from 1985-2011, shows that the trends are generally favourable (less fires), but also spatially heterogeneous - certain parts of Spain and Portugal have registered an increase in the number of fires and burned area, respectively. However, most studies actually predict an increase in wildfires and in burned area in the future under projected climate change (REgo et al. 2010; KHABArov et al. 2016; Alcamo et al. 2007). Apart for climate change, the reasons for an increase in wildfires are related to socio-economic changes leading to more hazardous landscape configuration, such as changes in land use and the abandonment of farmland which lead to an accumulation of surface fuel available for combustion ('Turco et al. 2016; Elia et al. 2016).

All these studies have one thing in common they point to the complexity of the issue of wildfires and the importance of human factors in fire ignition. In order to contribute to the effective prevention of fires, an integrated analysis encompassing both physical and socio-economic factors is therefore needed. Previous researches have used various methods in tackling this complexity, which mostly comprised a combination of remote sensing and different types of statistical analysis. It included different regression models (Estes et al. 2017; PAVLEK et al. 2016; Martinez-Fernandez et al. 2013), Bayesian belief networks model (BASHARI et al. 2016) and logistic regression modelling (KALABOKIDIs et al. 2007; DEL Hoyo et al. 2011; RIOS-PENA et al. 2017), to name a few. These studies demonstrate not only the importance of both physical and socio-economic factors in wildfire occurrence, but also an increase of the role the human factor plays in wildfire occurrence analysis. The analysis of human factors is often considered critical for fire risk estimation and for the development of future strategic planning in mitigating wildfire risk (KALABOKIDIS et al. 2002; RoDRIGUES et al. 2014; SHERry et al. 2019).

However, despite the potential for qualitative methods to provide novel, in-depth insights in environmental studies and explore new areas of research (Pahl and Wyles 2016; Kangsen Scammel 2010), human factor in wildfire occurrence analysis is still almost exclusively quantitatively measured and modelled. The analyses including qualitative methods in wildfire research are linked to topics such as perception of wildfire risk (CARrolL et al. 2004), wildfire safety preparations (KoKsAl et al. 2019; MCGEE and Russell 2003), shared social value (BRENKERT-SMITH 2010) or identifying policy target groups for wildlife risk prevention (FISCHER 2012), to name a few. This is aligned with general interpretivist and constructivist ideas where qualitative research is used in studying human behaviour and human perception of a phenomenon (KANGSEN SCAMmEL 2010; AsHLEY and BOYD 2006), while the study of drivers of wildfire occurrence is strongly positioned within the positivist paradigm (WING 2003). As a result, the use of qualitative data in wildfire occurrence analysis is still fairly rare.

Therefore, this research will employ a mixedmethods approach in analysing wildfire occurrence in the Croatian Mediterranean. The main aim of the study is to supplement the results from the literature and quantitative analysis with a set of semi-structured interviews and critically evaluate its contribution to the analysis. Our main focus is on changes in land cover as an indicator of socio-economic restructuring in the area, and the anthropogenic processes and practices which contribute to these land cover changes Processes, such as demographic ageing, agricultural abandonment and emigration which generally affect the land cover in the Mediterranean are prominent in the Croatian region of Dalmatia. These processes have been strongly affected by the socio-economic transition after the collapse of the socialist and communist system in the former Yugoslavia (Cvitanović et al. 2017), making it especially interesting for this kind of study. Dalmatia is also the most fire-prone region in the entire Croatia (ROSAVEC 2012) and is overall an understudied region in terms of wildfire occurrence.

To address this aim, we georeferenced wildfires recorded in the area during the 2011 and 2013 fire seasons. These fire seasons in Croatia were average or 
slightly above average compared to 1981-2010 longterm averages, making them suitable for this study (TOMAŠEVIĆ and VuČETIĆ 2014). In total, 445 fires larger than 0.5 ha were georeferenced, encompassing $95 \%$ of the total burnt area during the studied 24 months. The data on wildfires were then spatially analysed and correlated with a number of physical and socio-economic variables we hypothesized to influence wildfire occurrence. Further analysis of the results was achieved through semi-structured interviews with fire-fighters $(\mathrm{N}=13)$ and farmers $(\mathrm{N}=7)$ in the region. In designing the semi-structured interviews, we used the results from our spatial analysis of wildfires, but we supplemented it with long-term data from other studies in the region as well, to account for our relatively short period of analysis. The main hypothesis in this research is that changes in land cover and human management of land are the most important drivers of wildfire occurrence in the region, but that the best way to interpret the importance of anthropogenic drivers of wildfire occurrence is through mixed-methods research.

\section{Materials and methods}

\subsection{Study area}

Šibenik-Knin County and Split-Dalmatia County are located in the traditional Croatian region of Dalmatia (Fig. 1). They cover an area of almost $7,500 \mathrm{~km}^{2}$ or $13 \%$ of Croatian territory. These two counties have the highest recorded number of fires and are a part of a zone with the highest risk level of wildfires in Croatia (DZUS 2015), making it a suitable area for this kind of study.

In terms of relief, the study area comprises three distinct parts: the hinterland, the littoral and the islands. The littoral includes a narrow belt along the coast which is separated from the hinterland by mountain ridges and ranges that are generally parallel to the coast. The majority of the population lives in the littoral, mostly in urban settlements such as Split and Šibenik. The hinterland is a part of the Dinaric mountain system, with typical karst relief forms such as karst plateaus and dolines. Compared

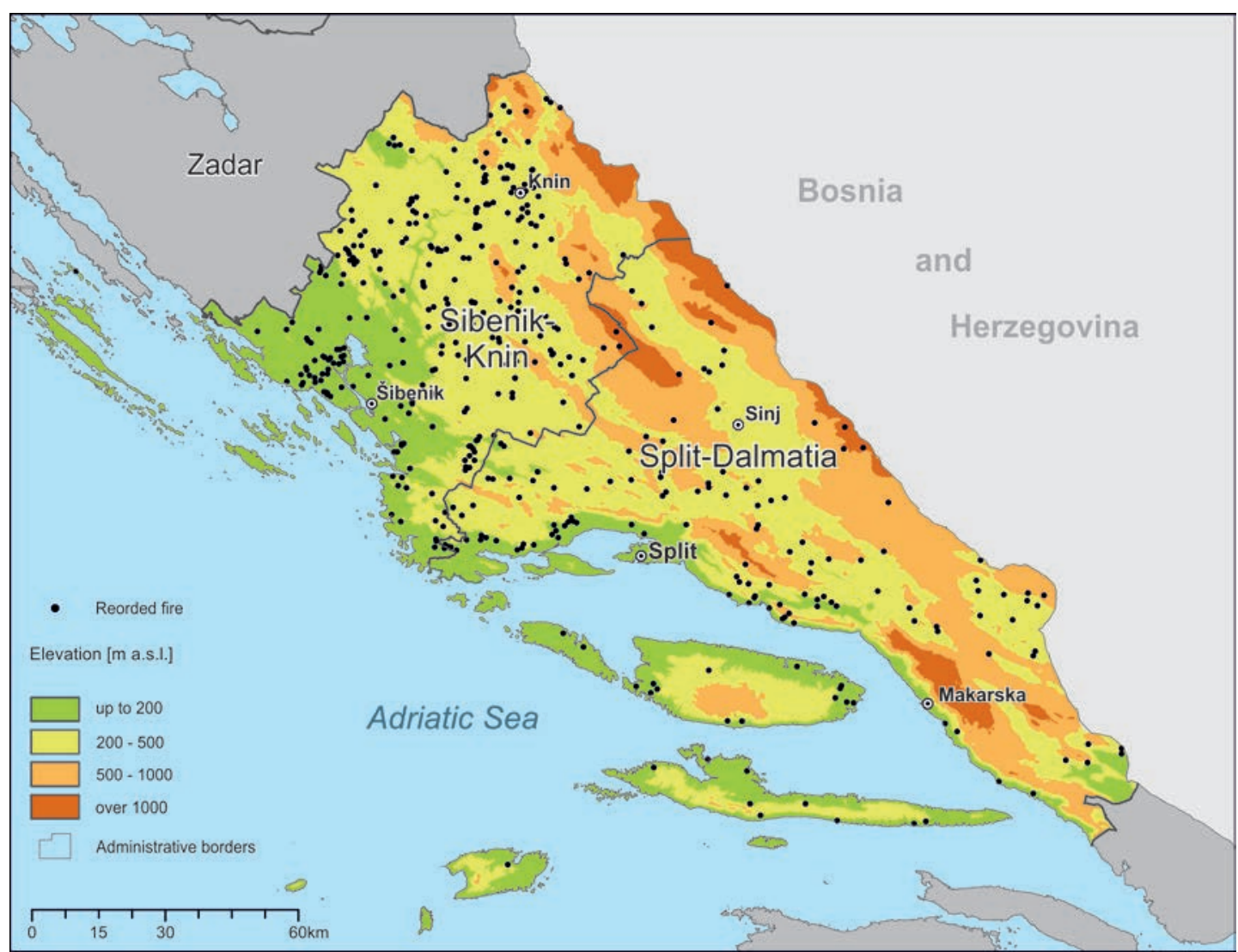

Fig. 1: Study area with main elevation categories and wildfires recorded during the study period. Data source: NASA et al. 2019; DZUS 2015. 
to densely populated and urbanized littoral, the islands and the hinterland are more sparsely populated, with predominantly rural population in smaller settlements.

The islands and the littoral are characterised by Mediterranean climate with dry and hot summer and rainy winters (Csa). Most of the hinterland has a moderately warm humid climate $(\mathrm{Cfa} / \mathrm{Cfb})$, while the highest parts of Dinara Mountain have humid continental climate (Df).

\subsection{Variables}

The fire data in the Northern and Central Dalmatia Region for 2011 and 2013 were obtained from the Firefighting Centre, State Administration for Protection and Rescue of Croatia (Državni zavod za zaštitu i spašavanje - DZUS 2015). Every fire had an approximate location (e.g. the nearest settlement, road junction etc.), date and time of fire breakout, date and time of firefighting intervention, the size of fire, types of land covers burned, and the type of an intervention vehicle. This analysis focused only on fires larger than 0.5 ha. Seventeen fires recorded in municipalities of Split and Solin were also excluded from the study because of lack of historical socio-demographic data in this area (needed for further analyses). Therefore, a total of 445 fires (95\% of all recorded fires) were included in our analysis (cf. Fig. 1). Fire data in our analysis includes the location of fire, date of occurrence, size of burned area, most dominant type of land cover burned, and elevation at which fire occurred. The two main dependent variables ( cf. Tab. 1)derived from these data were fire density and burned area index (BAI).

Digital elevation model was acquired from the EarthData (NASA et al. 2019). Elevations were divided into four categories (Tab. 2), representing the main landscape features of the region. The land cover data and digital topographic maps of Croatia were obtained from the State Geodetic Administration of the Republic of Croatia (Državna Geodetska Uprava - DGU 2015). The land cover in the area was divided into seven categories - agricul- tural land, grassland, shrubland (maquis), coniferous forest, deciduous forest, mixed forest and other land cover. The DGU (2015) map of land cover was used as auxiliary information during the georeferencing of the fires as well.

The selection of socio-demographic variables was based on previous research (ADAB et al. 2013; Catry et al. 2009; Nunes et al. 2016; Moreira et al. 2009), the availability of the data and the researchers' expert knowledge of the area. This data encompassed the main socio-demographic characteristics and processes in the area which were believed to have some relation to wildfire occurrence. They included general population changes (NuNES 2012; Oliveira et al. 2012), changes in agricultural population (Koutsias et al. 2010; Martinez-FernandeZ et al. 2013), tourist arrivals (VAiCiUlyte et al. 2019) and road density (Yocom et al. 2019; Ye et al. 2017; SADASIvuni et al. 2013), (Tab. 2). Data were obtained from the Croatian Bureau of Statistics (DZS 2015).

\subsection{Analysis}

All the analysed wildfires were georeferenced manually, using the approximate wildfire location from DZUS (2015), with the use of the DGU (2015) land cover map and the digital topographic map of Croatia 1:25,000 as auxiliary information. The wildfire data were then aggregated to municipal level in order to calculate both the fire density and the BAI. Municipalities were selected for this research as they are the smallest administrative units for which our socio-economic data exist.

The size and fire frequency per municipality were further analysed using the Global Moran's I and Anselin Local Moran's I to identify potential clusters of wildfires in our study region. All spatial analyses were conducted using ArcMap 10.2 software. Subsequently, the links between the independent variables on one side and fire occurrence (fire density and BAI) on the other were tested through Kendall's rank correlation coefficient. Additionally, the road density variable was analysed by employ-

Tab. 1: Analyzed dependent variables. Data source: DZUS 2015

\begin{tabular}{llll}
\hline Fire data & Level & Data processing & Dependent variable \\
\hline Number of fires & Municipality & Number of fires per $100 \mathrm{sq} . \mathrm{km} /$ year & Fire density \\
$\begin{array}{l}\text { Size of fire } \\
\text { (burned area) }\end{array}$ & & $\begin{array}{l}\text { Size of burned area per } 100 \mathrm{sq} . \mathrm{km} / \\
\text { year }\end{array}$ & Burned area index \\
\hline
\end{tabular}


Tab. 2: Analyzed independent variables

\begin{tabular}{|c|c|c|c|}
\hline Data & Level & Description & Categories (independent variables) \\
\hline \multirow{4}{*}{$\begin{array}{l}\text { Elevation } \\
\text { Source: NASA } \\
\text { et al. } 2019\end{array}$} & \multirow[t]{4}{*}{ Municipality } & \multirow{4}{*}{$\begin{array}{l}\% \text { of elevation categories per } \\
\text { municipality }\end{array}$} & $<200 \mathrm{~m}$ \\
\hline & & & $200-500 \mathrm{~m}$ \\
\hline & & & $500-1000 \mathrm{~m}$ \\
\hline & & & $>1000 \mathrm{~m}$ \\
\hline \multirow{8}{*}{$\begin{array}{l}\text { Demographic } \\
\text { and social data } \\
\text { Source: DZS } \\
2015\end{array}$} & \multirow[t]{8}{*}{ Municipality } & Population change 1961-2011 & Population change \\
\hline & & $\begin{array}{l}\text { Changes in population density } \\
1961-2011\end{array}$ & Population density \\
\hline & & Ageing index 1961-2011 & Ageing index \\
\hline & & $\begin{array}{l}\% \text { of active agricultural } \\
\text { population } 2001\end{array}$ & Active agricultural population \\
\hline & & $\begin{array}{l}\text { Population change of active } \\
\text { agricultural population } 1961 \text { - } \\
2001\end{array}$ & Active agricultural population change \\
\hline & & $\begin{array}{l}\text { Share of tourist arrivals in } \\
\text { population }\end{array}$ & Tourist nights \\
\hline & & $\%$ of unused land & Unused land \\
\hline & & $\mathrm{Km}$ of roads per 100 sq. $\mathrm{km}$ & Road density \\
\hline \multirow{7}{*}{$\begin{array}{l}\text { Land cover data } \\
\text { Sourec: DGU } \\
2015\end{array}$} & \multirow[t]{7}{*}{ Municipality } & \multirow{7}{*}{$\begin{array}{l}\% \text { of land cover category per } \\
\text { municipality }\end{array}$} & Agricultural land \\
\hline & & & Grasslands \\
\hline & & & Shrubland (maquis) \\
\hline & & & Coniferous forest \\
\hline & & & Deciduous forest \\
\hline & & & Mixed forest \\
\hline & & & Other land cover categories \\
\hline
\end{tabular}

ing $100 \mathrm{~m}, 200 \mathrm{~m}$ and $500 \mathrm{~m}$ buffers around all the mapped roads in the study area. The data source for the road network was the Croatian State Geodetic Administration.

Afterwards, the insights from this part of the study were used in designing semi-structured interviews and in selecting groups of interest which we wanted to interview (Fig. 2). A total of twenty respondents, thirteen fire-fighters and seven farmers were chosen for this. The aim was to gather useful information that would improve the knowledge on wildfires and wildfire protection practices in the area and help in checking and interpreting the findings of our statistical analyses. The interviews were carried out by telephone during January 2018. They lasted for an average of thirty minutes and the answers were written down. The data was collected until the saturation point was reached and little new information was obtained.
Out of the 13 interviewed fire-fighters, 10 were from the Šibenik-Knin County and three from the Split-Dalmatia County. The interviewees were commanders, shift managers and fire-fighters from the public fire brigade facilities from Šibenik, Knin, Drniš, Vodice and Split. Šibenik, Knin and Drniš had the highest number of recorded wildfires in our study, and Split is the largest settlement in our study area. The questions aimed at general information on the location of firefighting interventions, the ways wildfires spread and why, as well as the causes of wildfire and the quality and the type of prevention measures.

Four farmers interviewed in this research were from the Sibenik-Knin County, and three from the Split-Dalmatia County $(\mathrm{N}=7)$. The questions were related to farmers' experiences and practices regarding grass and shrubland burning as a form of agricultural management, their general agricul- 


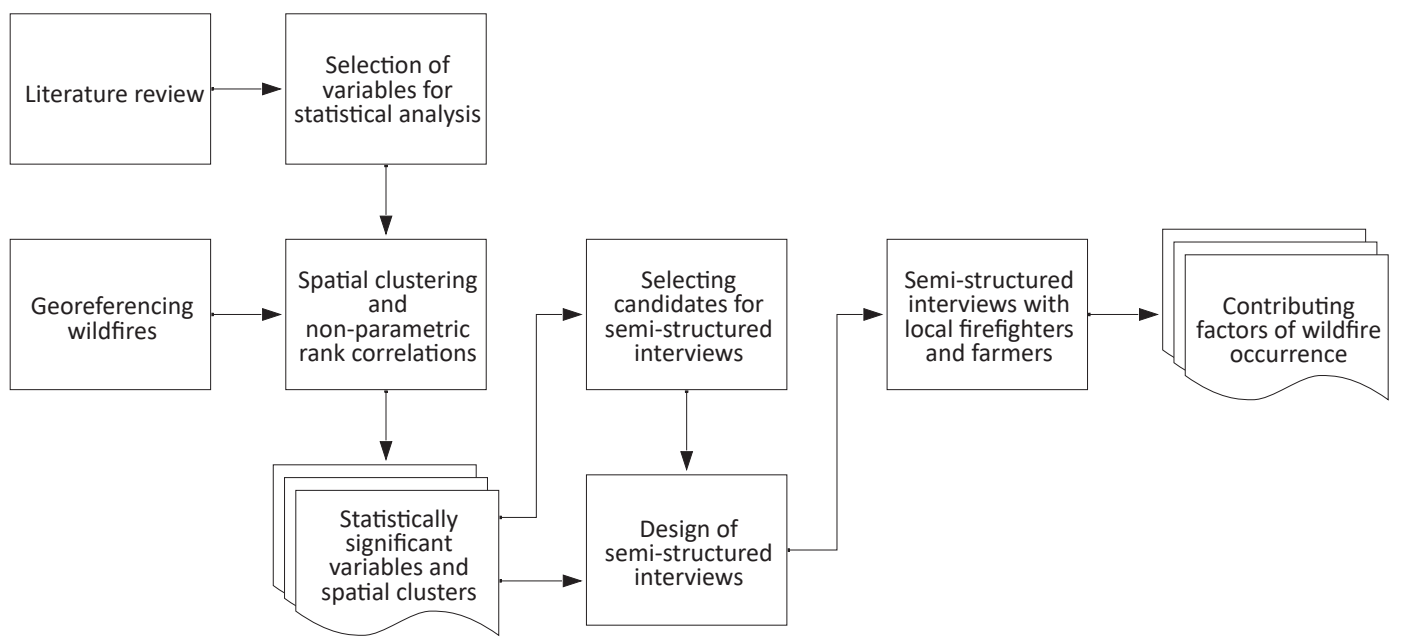

Fig. 2: Methodical approach and workflow

tural practices, personal experience with wildfires, preventive measures for fire protection and their opinions and attitudes towards firefighting policies and procedures.

\section{Results}

During the studied 24 months, around 12,500 hectares of burnt area was recorded in total, which is around $1.6 \%$ of the entire area. The largest recorded fire burned 5,600 ha of land, but $94 \%$ of fires were smaller than 100 ha. The median value was $10 \mathrm{ha}$, indicating the prevalence of smaller fires in the region.

The results show that the northern part of our study area - the Šibenik-Knin County - was characterized by a much higher number of fires compared to the Split-Dalmatia County. In fact, 35\% of all recorded wildfires were located in only four municipalities of the Šibenik-Knin County. They are Šibenik (53 fires), Drniš (37), Kistanje (34) and Knin with 32 recorded wildfires (Fig. 3).

\subsection{Land cover and elevation}

Figure 4 illustrates that the land cover of most municipalities is dominated by grassland or a mixture of grassland, forest and shrubland. In contrast, agricultural land and large forest characterise the landscape only in a few districts - mostly around large rivers and karst poljes (agricultural land) and islands and higher altitudes (forests).Grassland was the most frequently burned land cover type of all burned land cover types in 24 municipalities and grassland fires were the most common type of wildfires in the region (Tab. 3). Grassland fires were on average large in size (32 ha) and had a high fire occurrence per surface area (7.9 fires per $100 \mathrm{sq} . \mathrm{km}$ of grasslands). However, the largest fires were recorded in the deciduous (42 ha) and mixed forest (37 ha) category, with mixed forests also having a high fire occurrence. The highest fire occurrence was recorded in the shrubland (maquis) category (28 fires per 100 sq. $\mathrm{km}$ of maquis), but the fires were very small on average ( $9.7 \mathrm{ha})$.

Regarding elevation, more than a half of all fires occurred between 200 and $500 \mathrm{~m}$ and almost none at elevations higher than $1000 \mathrm{~m}$ (Tab. 4, cf. also Fig. 1).

\subsection{Fire density and burned area index (BAI)}

The highest annual fire density was recorded in the municipalities of Promina (9.4 fires per 100 sq. $\mathrm{km})$ Vodice (9.2 fires fires per 100 sq. km), Dugi Rat (9.1 fires per 100 sq. km) and Kistanje (7 fires per 100 sq. km). The highest BAI was in the municipality of Milna (7 958 ha burning per 100 sq. $\mathrm{km})$, mostly due to the 2011 Milna fire which was one of the largest recorded fires in Croatia since the 1980s and can be considered an outlier (MIFKA and VUČETIĆ 2012). Other municipalities with a very high BAI ( $>$ 1000) were Hvar, Dugi Rat, Ervenik and Vodice, but the median was relatively low (70). Both fire density and burned area index is shown in Figure 5. 


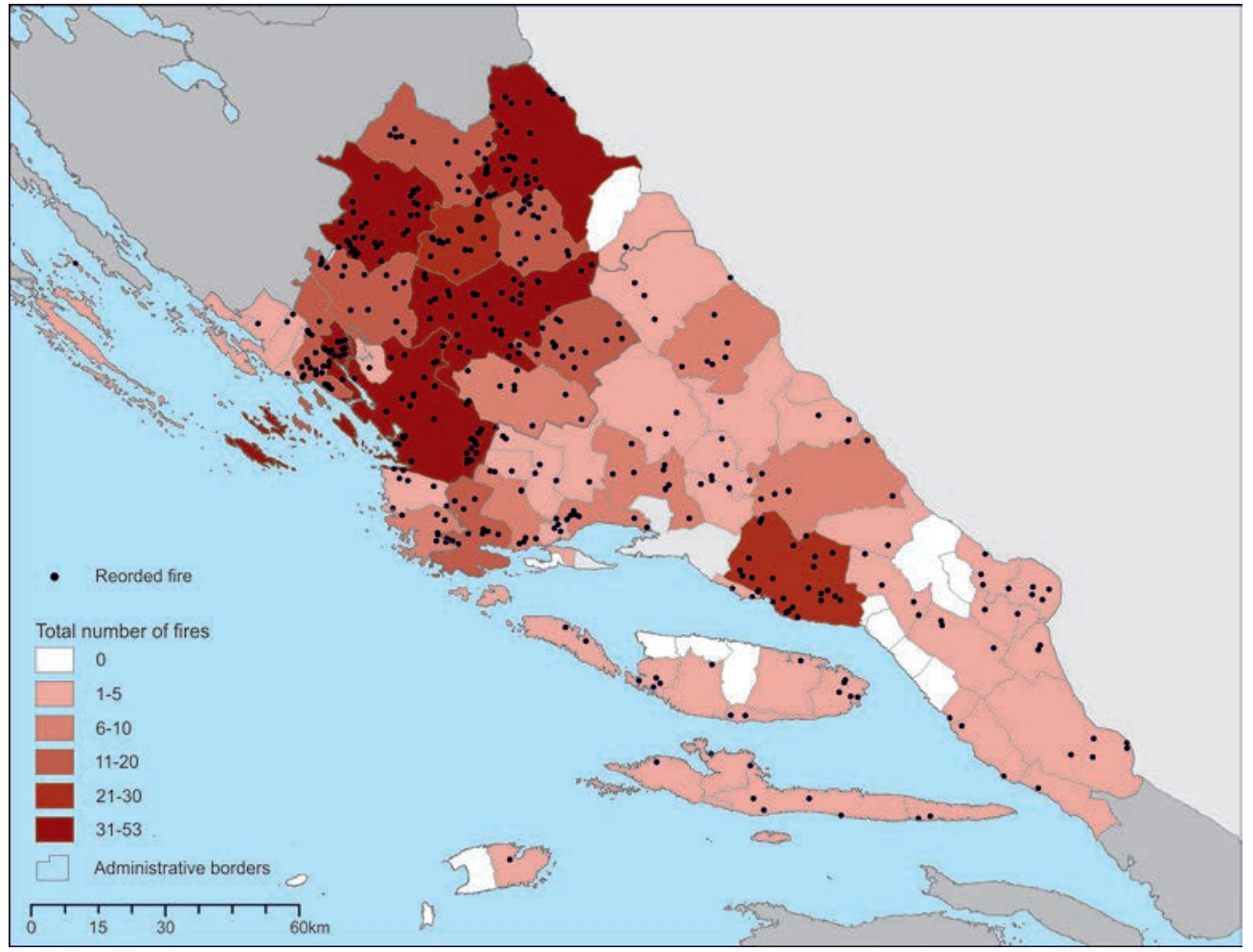

Fig. 3: Number of fires per municipality. Data source: DZUS 2015

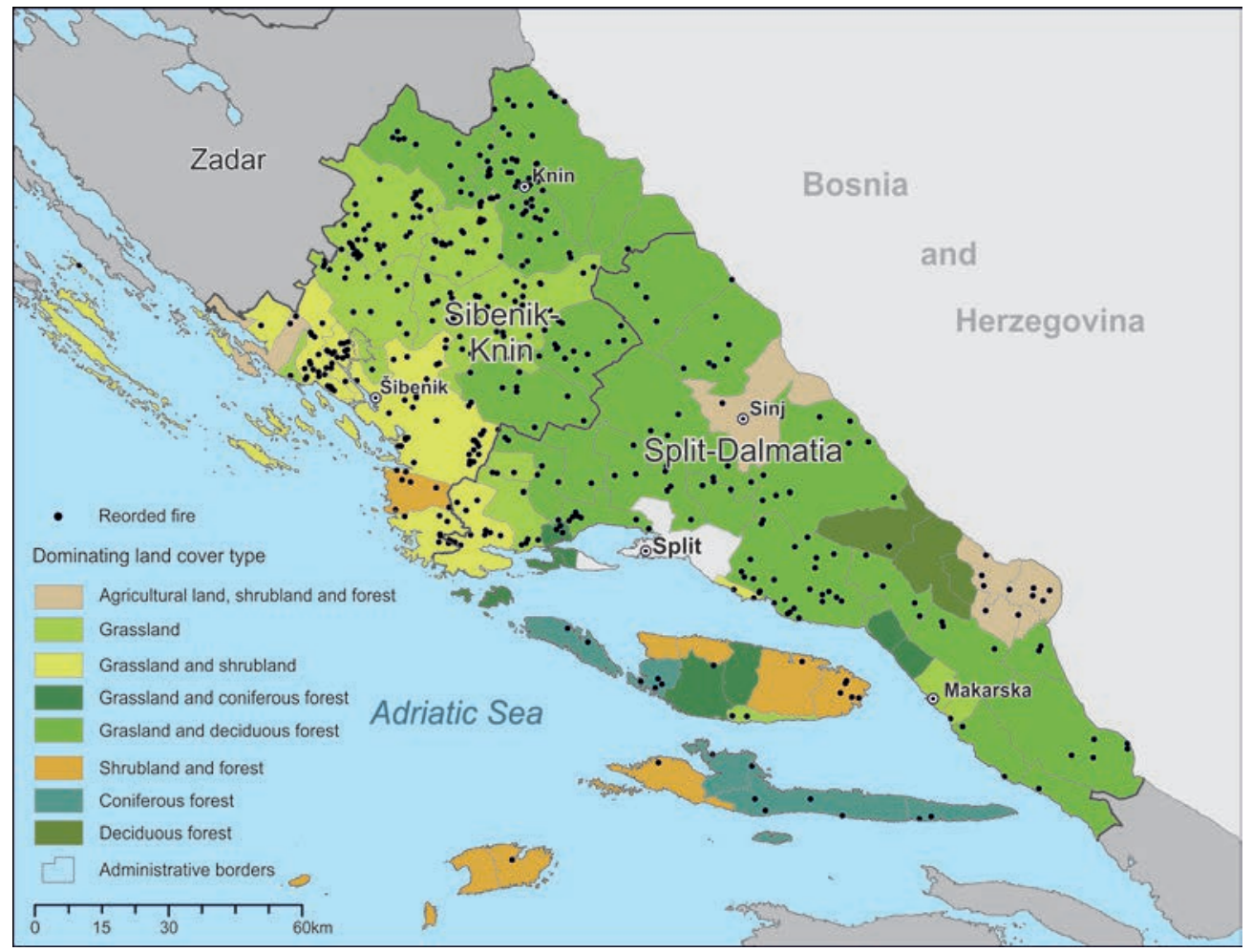

Fig. 4: Dominant land cover type. Data source: DGU 2015 
Tab. 3: Average size of fire and burning frequency per land cover type

\begin{tabular}{lcccc}
\hline Type of land cover & $\begin{array}{c}\text { Average size } \\
\text { of fire (ha) }\end{array}$ & $\begin{array}{c}\text { Fires per 100 sq. } \mathbf{~ k m} \\
\text { of surface area }\end{array}$ & $\begin{array}{c}\text { \% of land cover in } \\
\text { study area }\end{array}$ & $\begin{array}{c}\text { \% of all fires in } \\
\text { study area }\end{array}$ \\
\hline Agricultural land & 16.0 & 3.2 & 12.8 & 6.0 \\
Grassland & 32.0 & 7.9 & 38.2 & 43.6 \\
Shrubland (maquis) & 9.7 & 28.1 & 7.5 & 30.2 \\
Coniferous forest & 16.7 & 7.4 & 8.4 & 9.0 \\
Deciduous forest & 42.0 & 2.1 & 27.3 & 8.6 \\
Mixed forest & 37.0 & 24.2 & 0.1 & 2.7 \\
\hline
\end{tabular}

Data sources: DZUS 2015, DGU 2015

Tab. 4: Share of fires per elevation category

\begin{tabular}{ccc}
\hline Elevation category & \% of elevation category in study area & \% of fires in the study area \\
\hline$<\mathbf{2 0 0} \mathrm{m}$ & 22.7 & 31.4 \\
$\mathbf{2 0 0}-\mathbf{5 0 0} \mathbf{m}$ & 47.6 & 58.3 \\
$\mathbf{5 0 0}-\mathbf{1 0 0 0} \mathbf{m}$ & 24.6 & 9.5 \\
$>\mathbf{1 0 0 0} \mathrm{m}$ & 5.1 & 0.8 \\
\hline
\end{tabular}

Data sources: DZUS 2015, DGU 2015
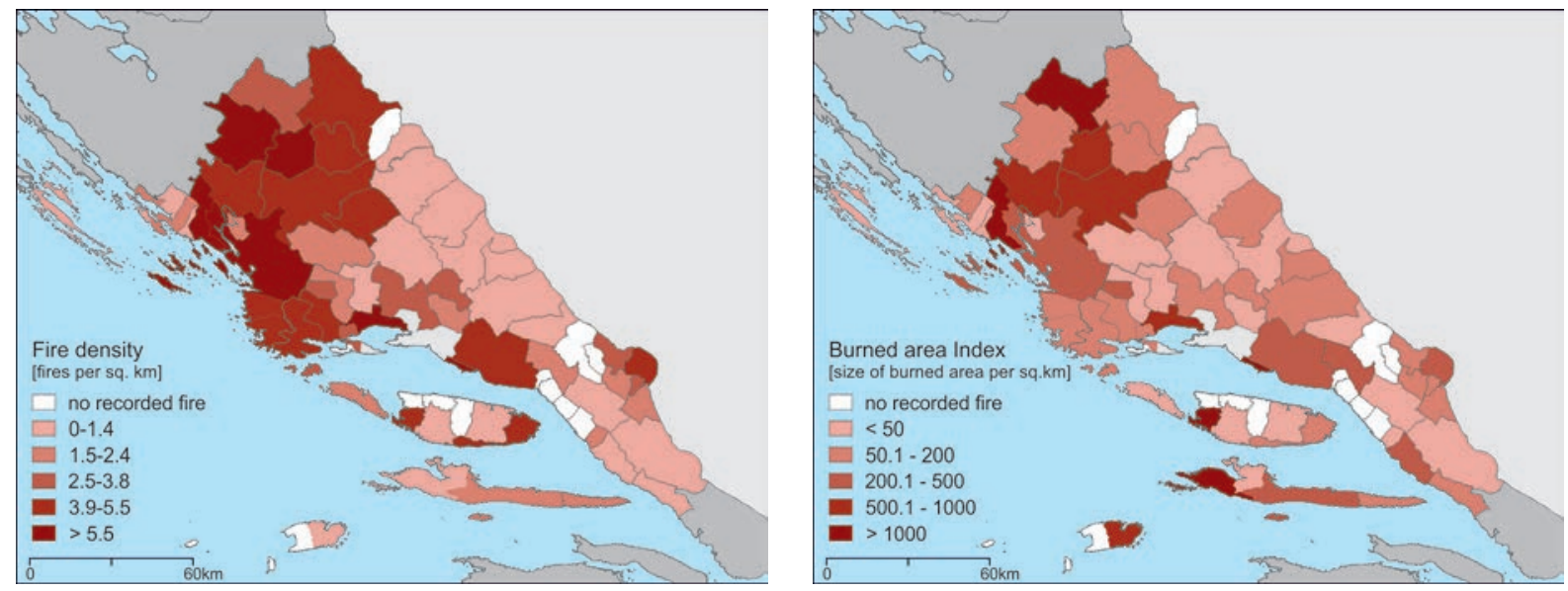

Fig. 5: Fire density (left) and burned area index (right). Data source: DZUS 2015

\subsection{Spatial clustering of fires (Moran's I)}

The Global Moran's Index confirmed that there is significant spatial clustering of wildfires in Dalmatia ( $\mathrm{I}=0.57, \mathrm{z}=7.55, \mathrm{p}<0.001)$. Anselin Local Moran's I identified clusters of wildfires in the Šibenik-Knin County. Also, Anselin Local Moran's I was calculated for burned area index to discover if there is clustering of municipalities with large burned areas. The results showed only one high-low outlier and one low-high outlier on the island of Brač, both related to the 2011 Milna wildfire. Anselin Local Moran's I results on fire density is shown in Figure 6.

\subsection{Kendall's Tau Correlations}

The relationship between the dependent and the independent variables in our research were tested by Kendall's Tau correlation. Fire occurrence was positively correlated with elevations $200 \mathrm{~m}-500 \mathrm{~m}$, grassland and mixed forest land cover categories, population in 2011 (cf. Fig. 7), and agricultural population in 1961. BAI was positively correlated with agricultural population in 1961 and 2001, the same altitudinal and land cover categories and population in 2011, but also negatively correlated with population change 1961 - 2011 (cf. 


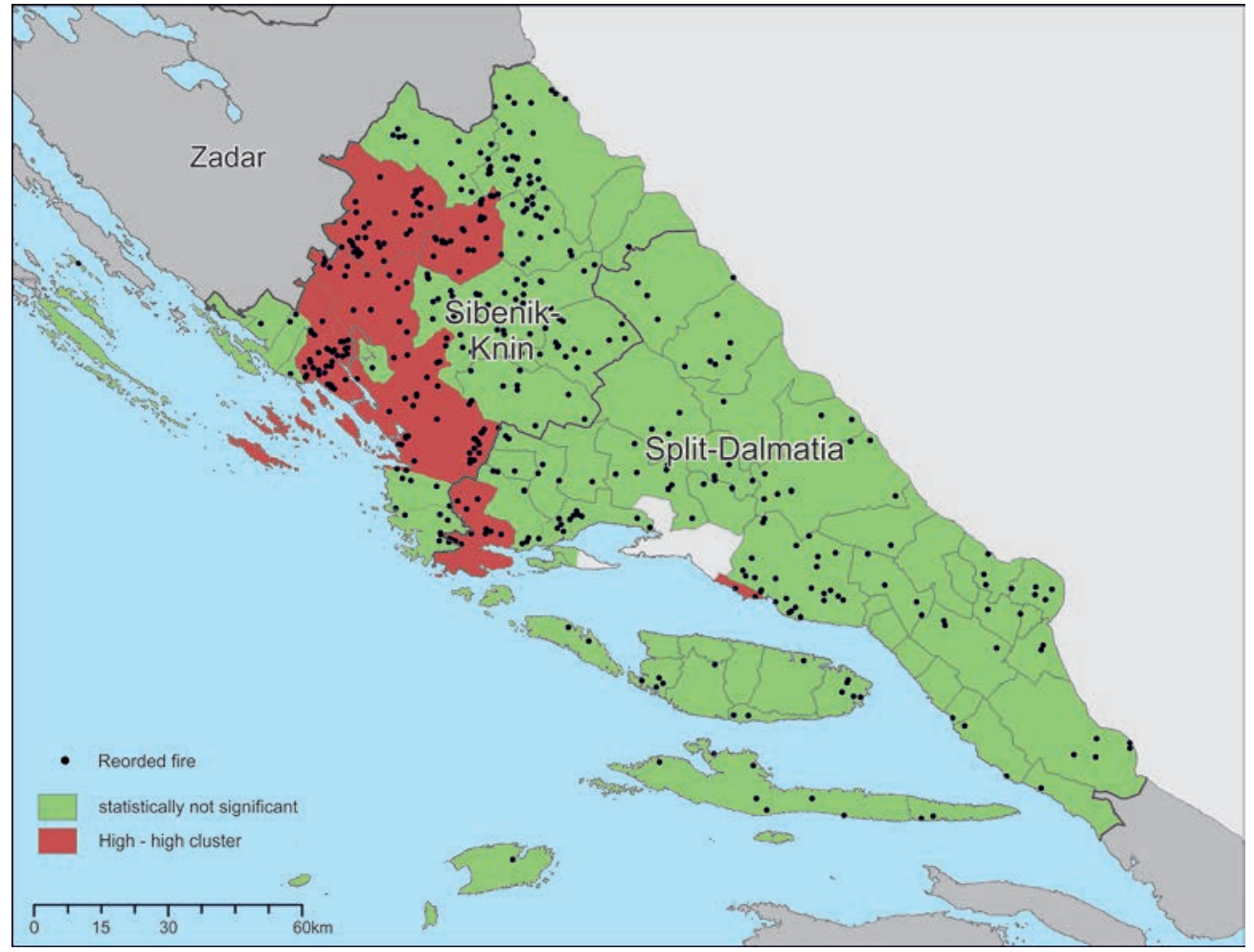

Fig. 6: Results of Local Moran's I of fire density. Data source: DZUS 2015

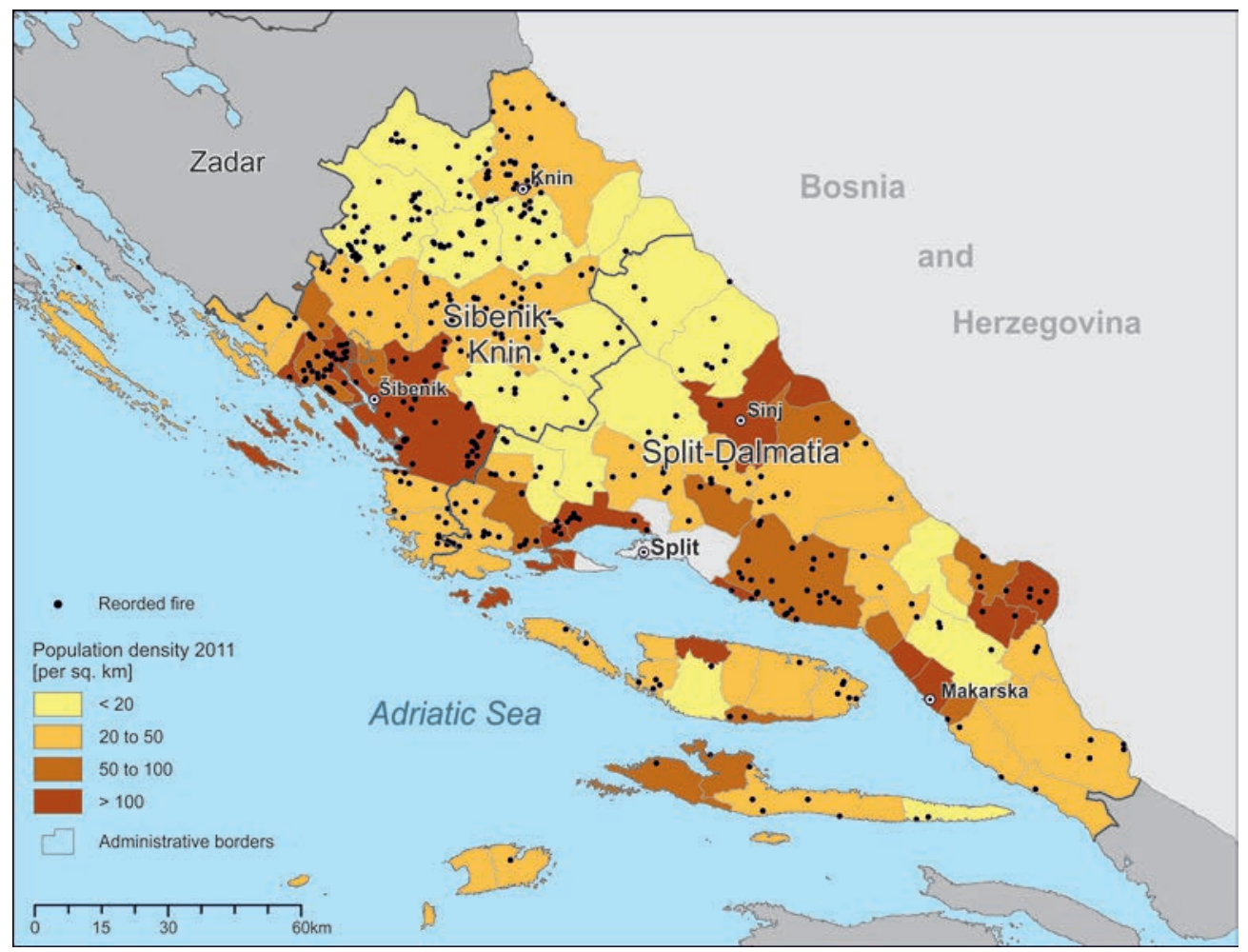

Fig. 7: Locations of all recorded fires larger than 0.5 ha during the studied period and the population density by municipality. Data Source: DZUS 2015, DZS 2015. 


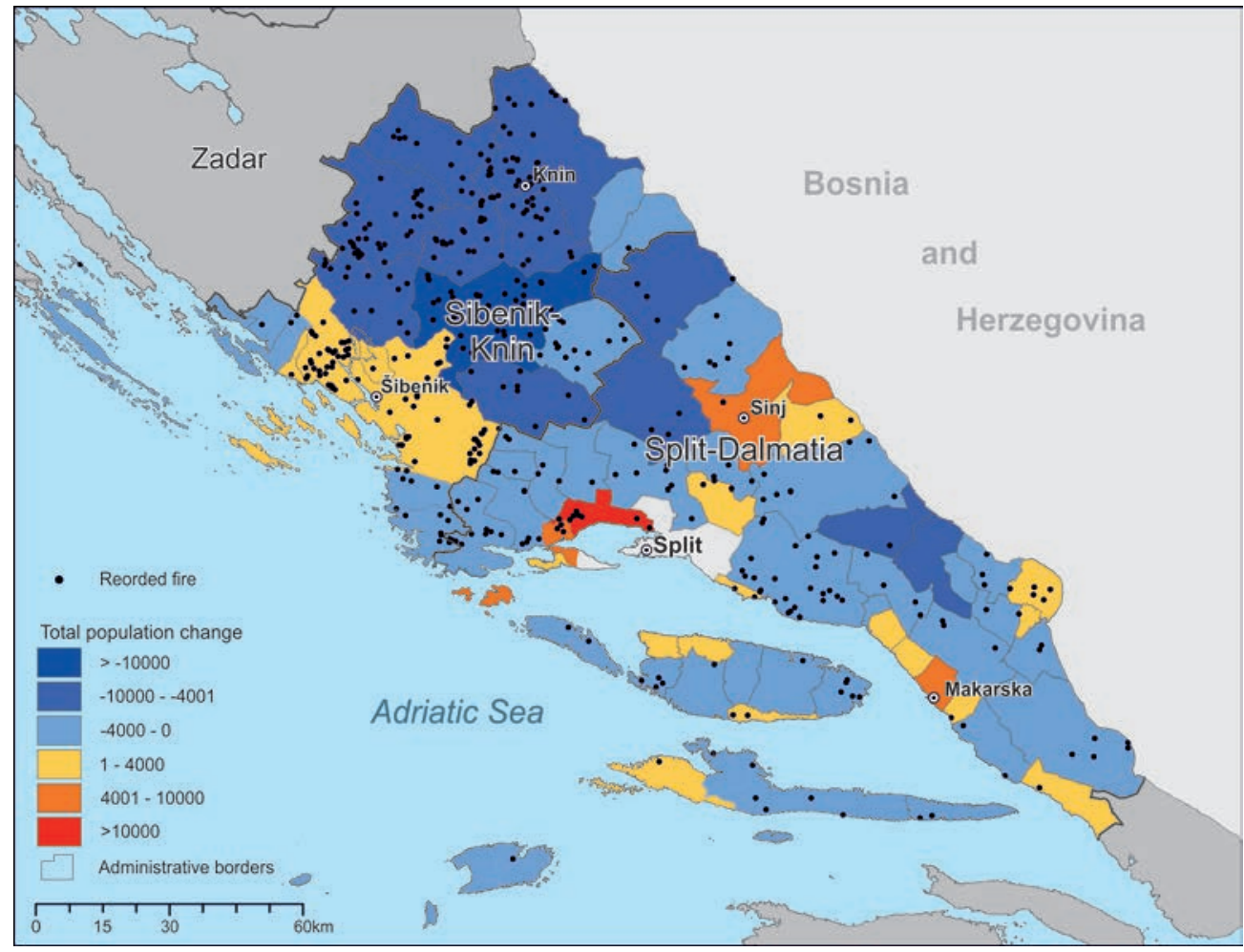

Fig. 8: Population change between 1961 and 2011. Data source: DZS 2015

Tab. 5: Statistically significant variables correlated with fire occurrence and burned area index (BAI)

\begin{tabular}{lccccccc}
\hline & $\begin{array}{c}\text { Population } \\
\text { change } \\
1961-2011\end{array}$ & $\begin{array}{c}\text { Agricultural } \\
\text { pop 1961 }\end{array}$ & $\begin{array}{c}\text { Agricultural } \\
\text { pop 2001 }\end{array}$ & Elevation & $\begin{array}{c}\text { Population } \\
2011\end{array}$ & $\begin{array}{c}\text { \% of } \\
\text { grassland } \\
\text { cover }\end{array}$ & $\begin{array}{c}\% \text { of } \\
\text { mixed } \\
\text { forest } \\
\text { cover }\end{array}$ \\
\hline $\begin{array}{l}\text { Fire } \\
\text { occurrence }\end{array}$ & - & $0.246^{* *}$ & - & $0.221^{* *}$ & $0.193^{*}$ & $0.217^{* *}$ & $0.322^{* *}$ \\
BAI & $-0.240^{* *}$ & $0.373^{* *}$ & $0.314^{* *}$ & $0.286^{* *}$ & $0.297^{* *}$ & $0.211^{*}$ & $0.254^{* *}$ \\
\hline
\end{tabular}

${ }^{*} \mathrm{p}<0.05 ;{ }^{*} \mathrm{p}<0.01$. Data source: DZS 2015, DZUS 2015

Fig. 8). Correlations were generally low, but statistically significant (Tab. 5). The buffer analysis showed no correlation of road density with either fire density or BAI.

\subsection{Interviews with fire-fighters}

The first part of the interview focused on reports of fire incidents and the locations where firefighting interventions generally take place. Most frequently, fire incidents were related to open areas in urban areas, as well as mountainous and less accessible regions. Apart from that, the interventions were also more frequent on non-cultivated and abandoned agricultural surfaces, which were reportedly on the increase in the region. Regarding the people who report wildfire incidents, a large number of wildfires are reported by the residents and tourists through phone calls.

The next objective was to find out how many interventions were related to accidental fires (especially in connection to the practice of burning vegetation as a way of clearing agricultural land), as well as other common causes of wildfires in the region. Most respondents stressed that this largely depends on the time of the year. There is a much greater number of interventions caused by the ignition of agricultural waste and cleaning of the agricultural lands during spring. On the other hand, the largest number of other types of accidental wildfires occurs during 
summer. Most fire-fighters believe that pyromaniacs are the cause of many wildfires in the area and that the judicial system is too lenient: "Intentionally caused wildfires prevail; it is impossible for such a large number of wildfires to happen at a certain area, especially when they occur at the same time. In the binterland of Vodice the number of intentionally caused wildfires is at record high; it is not possible for wildfires to occur in that area by chance, and 5 or 6 time more often than in other parts of the country". For a smaller number of wildfires, the cause appeared as easily identifiable - lightning, electric sparking, uncontrolled and unsupervised open fires (often waste burning) etc.

Several questions were related to different factors which cause wildfires to spread rapidly across large areas. Almost all fire-fighters emphasised the problem of terrain configuration, drought, winds which rapidly change direction, the type of vegetation (with grasslands and maquis shrubland being the most fire-prone types of vegetation), as well as issues of inaccessibility. Regarding material damage caused by wildfires, the respondents highlighted the difference between different types of land use/ cover, claiming that the largest material damage was on agricultural land: "Material damage occurs, but also buman lives are in jeopardy. Olive groves, fig trees and forests most frequently sustain some kind of damage, but when forest burns, consequences are most relevant for the Croatian Forests $L t d^{\prime \prime}$; but rural and urban residents regard destroyed crops and orchards as the most significant type of damage". Burnt maquis shrubland was generally not seen as material damage. One respondent did recognize the problems occurring after wildfires, such as soil erosion, silting up of water courses and rockslides, which have a major effect on the local population.

The next part of the interview dealt with firefighting interventions and general wildfire prevention measures. The previously mentioned problems regarding inaccessible areas, abandoned agricultural and a lack of fire hydrants were emphasized: "The biggest problem is the lack of accessible paths, we tend to reach the locations of wildfires with great difficulty, our vehicles are not able to traverse the path, so quite often we have to walk and carry the necessary equipment, or we bave to go by a helicopter. A great deal of problems is caused by non-cultivated and abandoned land; people do not take care of it and [the locals] neglect their forests as well. Sometimes we are limited by the lack of the fire bydrant network." The fire-fighters emphasised that most of these things are outside their jurisdiction, but had several suggestions regarding potential

1) Approx. $78 \%$ forests in Croatia are state-owned, managed by the Croatian Forests Ltd. measures, instruments and activities for the prevention and reduction of the number of wildfires. The suggestions included better surveillance and supervision of agricultural waste burning, and fines for households which do not manage their agricultural land properly. The importance of educating local population was often mentioned: "Additional education of the local residents is required, the goal is not to prevent them from burning their waste, but it should be organised, with a municipal officer or a fire-fighter present". Some fire-fighters suggested different practices: "The locals burn their plant-based waste, however it could be used differently, and it could be used to produce natural compost to enrich the soil". The issue of abandoned agricultural land was repeatedly mentioned here as well. Some of the respondents claim that a few decades ago there was much less abandoned land because it was either cultivated or used for grazing. Non-cultivated land was almost non-existent. Nowadays, the same land is increasingly covered in shrubs and forests, increasing the amount of fuel for wildfires. The lack of communication between different relevant organizations, and the issue of non-resolved property ownership in the area were also mentioned.

The last question in the interview was about the possible reasons why the Šibenik-Knin County has the largest number of fires per year in Croatia. Most of the respondents agree that it is due to specific natural-geographic characteristics of the region such as terrain configuration combined with dry weather and wild Mediterranean vegetation. The fire-fighters agreed that the key thing is to deal with the problem of abandoned agricultural land, followed by an inadequate network of fire trails. An integrated spatial planning strategy which would include fire-fighters was seen as the best way of preventing wildfires in the region in the future.

\subsection{Interviews with farmers}

The first part of the interview focused on the issue of abandoned agricultural land. Most of the respondents stated that they maintain almost all of the agricultural land they own. However, some parts of privately-owned woodlands were reported as unmanaged, but it was seen as of lesser importance. Regarding the practice and the regulations pertaining to agricultural waste burning in the area, almost all of the respondents stated that they are familiar with the rules. Three respondents said that they don't practice waste burning on their land at all. Others practice it either during winter, or in the 
spring, before the summer ban comes in place. All the respondents pointed out that they never had any problems or negative consequences due to the agricultural waste burning. It was mostly due to precautionary measures such as checking the weather forecast and gradual burning of waste in smaller piles.

On the other hand, almost all respondents stated that they experienced wildfires in immediate proximity to their estate. Some added that in such cases they tried to protect their estate by spraying water pre-emptively, but in most cases, they felt the best they could do was calling the fire department. However, one of the respondents talked about his experience with fire spreading to his estate: "Everything burned down, olive groves, the vineyard, my vegetable garden, the orchard, two tractors, cattle pen and some of the cattle there. It set me back 20 years. The fire spread rapidly, and my land was cultivated, it wasn't overgrown!"

However, the problem with abandoned or uncultivated agricultural land was often mentioned. One of the respondents claimed that only legal regulation could change these inadequate practices: "People will not maintain their land unless they are forced to do so. Everyone should clear and maintain their own land, because it is difficult for the fire-fighters to reach a fire if the paths have not been cleared. People should be aware of the problem themselves and not wait until it's too late."

When it comes to prevention methods and practices, most respondents stated they did not use any particular method. Three respondents pointed out that they considered clearing the land and cultivating the land as one, because, as one of them explained, overgrown land can easily catch on fire, particularly if there is an extreme drought. One respondent reportedly had a fire extinguisher in his building, and two other had water pumps or water taps in their fields. However, one of the respondents pointed out that the water supply in the area was generally inadequate - the fire hydrants had only been installed recently, so most people still depend on cisterns or collected rainwater.

The farmers were then asked about their level of satisfaction with the fire department in the area. Five respondents stated that they were pleased with the speed and course of action of the fire department. Two respondents lauded the fire department for their speed and effectiveness, and several respondents pointed out to inadequate working conditions of the fire-fighters due to obsolete equipment and the lack of financing. One respondent stated that more should be done on preventing fires, instead of focusing on putting out the fires after they had already started. These suggested preventive actions included plant- ing fire-resistant trees and olive groves. Several respondents claimed that it is difficult to expect more, especially taken into consideration a large number of deliberate fires started by arsonists.

When asked about existing activities or workshops on rules and regulations regarding agricultural waste burning, most respondents were not informed about any kind of events, but several reported that the information is regularly broadcasted in the media and that there is access to it. One of the respondents claimed that creating and maintaining communal areas where tools and equipment for fighting fires would be kept would be beneficial. More fire trails were also seen as a necessity. One of the farmers reported that local hunting societies usually try and maintain the existing fire trails, but that more involvement from local population (especially the young) is needed.

Several respondents complained about general neglect of smaller roads in the area, but about the afforestation activities conducted in the area as well. Reportedly, Aleppo pine is often used during such activities, which is perceived by the local population as invasive fire-prone species.

The final question for the farmers was about the fact that Šibenik-Knin County has the highest incidence of fires in Croatia. Most of the respondents claimed that the main causes were the cessation of traditional pasturing, an increase in overgrown areas covered with shrubland and weeds, dry karst features, general inaccessibility of the terrain and emigration from the area. Other reasons include mine fields remaining from the 1991-1995 armed conflict in Croatia and unresolved land property disputes inherited from the socialist era. One of the respondents emphasised the role of arson once again.

\section{Discussion}

Statistical analysis in this research demonstrated the importance of both physical and socio-economic drivers of wildfires in the study region. Mediterranean shrubland (maquis) was a land cover type with the highest number of fires per area surface, and grasslands had the highest number of fires overall. Quantitative analysis also pointed to the importance of elevation, but to agricultural population and changes in overall population in our study area as well. These findings were then supplemented with qualitative analysis through semi-structured interviews with fire-fighters and farmers from the study region which further explained some of the correlations in this study, but also provided us with new insights. 


\subsection{Elevation}

The geomorphology of an area affects the process of secondary succession of vegetation and therefore on the dynamics of the fire (KALABOKIDIs et al. 2007). Elevation was identified as a variable that plays a significant role in wildfires in different parts of the Mediterranean (KALABOKIDIS et al. 2007; GoNZALEZ et al. 2006), with lower to mid-elevations being a contributing factor in a large number of fires and burnt areas. This is in accordance with the results from this study, where elevations between $200 \mathrm{~m}$ and $500 \mathrm{~m}$ were correlated with both fire density and BAI. Seeing that most of the fires are anthropogenic in origin, which was confirmed by the fire-fighters, high elevations are not suitable for the development of fires due to very low population density and scarce vegetation. Interviewed fire-fighters pointed out that the lowest elevations along the coast do not favour the development of fires, since these are very densely populated areas where fires seldom occur, but are also rapidly extinguished, while mid-elevation areas are most suitable, considering the type of land cover and lower population densities.

\subsection{Land cover}

Depending on vegetation structure, fuel load and composition, certain types of land cover are characterized by a larger number of fires and high fire susceptibility (Moreira et al. 2009). Barros et al. (2014) showed that shrubland and coniferous forests are more fire prone compared to agricultural crops and deciduous forest. Oliveira et al. (2013) showed that shrubland, grasslands and sparsely vegetated areas had higher fire selectivity in nearly all countries in the Mediterranean. Similar results were found in this research - Mediterranean shrubland (maquis) was the most fire-prone land cover type, and grasslands had the highest number of recorded fires overall. Furthermore, coniferous forest was found to be almost twice as fire prone as deciduous forests, but agricultural land had a quite high fire occurrence as well.

However, in this research only grasslands and mixed forest were found to be correlated with fire occurrence and BAI on a statistically significant level, but not shrubland (maquis). The category of Mediterranean shrubland is most commonly found in Northern Dalmatian municipalities, but still grasslands dominate in these areas. A more detailed analysis has shown that in these municipalities char- acterized by a high percentage of grasslands it was often shrubland that was burning, not grasslands. By generalizing data on a municipal level, data loss has occurred which affected the outcome of our statistical analysis.

Through the interviews, abandoned agricultural land was highlighted as one of the land cover types characterized by a high number of fire-related interventions by the fire-fighters. The connection between wildfire occurrence, shrubland and abandoned agricultural land is usually explained through the process of socio-economic restructuring which has been evident in most parts of the Mediterranean during the past century. The abandonment of agricultural land and agricultural practices such as pasturing causes an increase in the natural vegetation cover, so former pastures and fields are becoming shrubland (Romero-Calcerrada and Perry 2004). For example, the agricultural land in Portugal's Minho region in a period of years has decreased by $29 \%$ and was mostly replaced by underbush and deciduous forest, while low vegetation was replaced by tall vegetation and forest (Moreira et al. 2001). Similarly, in Spain's Central Pyrenees region, 78.9\% of cultivable land was abandoned in the period between 1940 and 1981 and was replaced by homogenous underbush (AzEvedo et al. 2011). Shrubland (maquis) generally has higher fire susceptibility also due to its location on the steeper slopes which are more fire prone, intentional burning for creating pastures, and higher rate of fire spread (MOREIRA et al. 2009; CurT et al. 2013).

Research conducted in the wider area of northwestern Dinarides (encompassing our study area) has documented a process of de-agrarianization and de-ruralization during the last century (GAMs and GaBROVEC 1999). These processes resulted in secondary succession on pastures and meadows, which was reported during the interviews with fire-fighters and farmers as well. De-agrarianization, de-ruralization and depopulation in general were highlighted by firefighters as key processes which influenced land abandonment and consequently higher fire occurrence in Northern Dalmatia region. Similarly, interviewed farmers emphasized the cessation of traditional livestock pasturing and as one of the key factors which facilitated an increase in shrubland.

Like shrubland, grasslands tend to be more fireprone than other vegetation cover types (Oliveira et al. 2013). Grasslands were identified as a land cover with large fires in size ( $32 \mathrm{ha})$ and with the highest overall number of recorded fires (over 40\% of fires were in grasslands) in the study area. This 
is due to their intrinsic characteristics regarding speed of ignition, but is often related to different agricultural practices as well (Oliveira et al. 2013). Grasslands and shrubland can be seen as naturally highly intermingled vegetation categories, without a clear border separating them (PAVLEK et al. 2016), but also as different stages of the same process of secondary succession. This again points to the importance of agricultural abandonment and cessation of traditional cattle pasturing in the analysis of fire occurrence (BONET 2004; CASADO et al. 1986). A study in Corsica has showed that fires occur more frequently in early and middle stages of secondary succession (Mouillot et al. 2003). Other research in the area of Dalmatia also pointed to the importance of grasslands in wildfire occurrence analysis (PAVLEK et al. 2016). Agricultural activities on grassland, such as spring clearing and burning of agricultural waste were also highlighted as a significant fire triggers in this study through interviews with fire-fighters and farmers.

\subsection{Agricultural abandonment and population change}

Another variable which has shown a correlation with the frequency of fires is the general population decrease in the $1961-2011$ period. This process is characteristic for Dalmatian rural hinterland, meaning that it is mostly agricultural population which decreased in the area (cf. Fig. 8). However, due to simultaneous processes of rapid depopulation and decrease in agricultural population, the share of agricultural population in the municipalities in the area did not change as dramatically. The areas with a higher share of agricultural population in 1961 were correlated with higher fire frequency and BAI, and (unlike fire frequency), BAI was correlated with a higher share of agricultural population in 2001 as well. This suggests that there is a concomitant relationship between wildfires and areas which suffer from a general population loss, but which are still characterized by a high share of agricultural population, i.e. rural areas in the hinterland.

Decrease in the total number of (agricultural) population and a decline of traditional agricultural activity is a process that has occurred not only in Croatia, but in other parts of the Mediterranean as well (Romero-Calcerrada and Perry 2004). This has particularly affected mountainous areas, where agriculture is less competitive, with limited productivity, and a reduced adjustment capacity when com- pared to other, more accessible areas. These limitations have caused a lack of agricultural intensification and modernization in mountainous areas, which have thus caused these areas to become abandoned (AzEvedo et al. 2011). Examples of these processes can be found in Spain, where they have begun approximately 50 years ago (Romero-CALCERRADA and PERry 2004). In Portugal, negative agricultural indicators were a reflection population decline and agricultural activity from the 1950s to the 1990s (Moreira et al. 2001). In Croatia, the islands have had the highest rate of abandonment of agricultural areas, due to high emigration. However, the total percentage of abandoned arable land in Zadar and Sibenik-Knin County was more than a staggering $70 \%$, which was unquestionably a consequence of the war in the period from 1991 to 1995 (GAMs and Gabrovec 1999).

This process of agricultural abandonment and depopulation in Croatia as well as other parts of the Mediterranean has caused a change in the regime and the behaviour of fires, with an increase towards bigger and more intensive fires (AzEVEDo et al. 2011). The increased risk of fires is mostly influenced by homogenization of ground cover and increase in easily flammable fuels, like the aforementioned abandoned pastures (Romero-Calcerrada and Perry 2004). This was confirmed by our statistical analyses on land cover, as well as qualitative research. During the interviews, the fire-fighters themselves pointed out that a large number of their interventions was linked to abandoned or semi-cultivated agricultural areas, whose number is reportedly on the increase due to abandonment of agriculture, but to general depopulation trends as well.

In case of suggesting measures to prevent wildfire occurrence, previous research has demonstrated that conserving the traditional use of fire might be of interest (CARMENTA et al. 2011), but also that different stakeholders might have differing opinions about it. In the study by FlatLey et al. (2011) in the USA, farmers claimed that agriculture and cattle pasturing are the most efficient measures to control the growth of vegetation and maintain pastures, while conservationists claimed that farmers carry the blame for the high number of fires, due to their burning of large amounts of biomass. Similar results were found in the qualitative part of this study: continuing existing traditional agricultural practices, such as burning of agricultural waste or clearing the land from weed, were seen as a contributing factor to wildfire risk by fire-fighters, while the farmers believed this was a good practice to prevent wildfires. 
It seems that in areas with a net population loss and an increase in secondary succession, traditional agricultural practices of agricultural burning can no longer be considered as a useful wildfire prevention method, but could be if adequately managed. This could be a consequence of climate change which either reduced the number of available days for agricultural burning or moved it to earlier spring or later autumn months. Some recent studies have demonstrated the success prescribed agricultural burning have in preventing high-intensity fires (DUANE et al. 2019), but the evidence of the effects of climate change on the frequency, seasonality and interannual variability of suitable prescribed burning weather conditions is still inconclusive and spatially variable (Clarke et al. 2019).

Finally, both farmers and fire-fighters in this research talk about wildfires as a risk to only human lives and property, while other issues such as biodiversity and ecosystem services are mentioned just once. This could create conflicts when developing future wildfire risk management plans which need to be integrated, multi-dimensional and long termbased (Jolibert and Wesselink 2012; Chapman et al. 2019). Such conflicts include multiple actors at multiple levels and can be detrimental to both conservation initiatives as well as human lives and livelihoods (Hodgson et al. 2019; WoOdrofe et al. 2005). To increase the uptake of such plans, they need to be based on multiscale studies that involve all stakeholders and consider local and global impacts on biodiversity. Social scientists, scholars in the humanities, local stakeholders have all been recognized as key partners, but their involvement remains limited (BONEBRAKe et al. 2019).

\section{Conclusion}

The use of quantitative methods in this study enabled us to establish a correlation between wildfire occurrence and a set of physical and socio-geographic variables in the region. The wildfires in Dalmatia were mostly occurring in rural areas characterised by a high share of agricultural population and by general depopulation. Grasslands and shrubland were identified as the most fire-prone land cover. The qualitative part of the study helped in explaining the established correlations, but provided us with some new information as well.

Processes such as littoralization and the abandonment of traditional agricultural practices (especially pasturing) were seen as a contributing factor to wildfire risk. Homogenization of land cover and an increase of flammable fuels played an important role, but through qualitative research we discovered differing opinions on the practices of prescribed agricultural burning as a fire prevention strategy. While fire-fighters claim that agricultural burning is one of the main causes of wildfires, the farmers believe it is (still) a successful strategy in preventing large fires, but the research on this topic is still scarce and inconclusive.

The qualitative analysis also demonstrated that deliberate ignition is a factor in wildfire occurrence. This could be investigated even further through qualitative research, including interviews with e.g. police officers and planners or through archival records of fire offenses, which in this case might be more appropriate than any form of statistical analysis. Interviews proved to be a valuable tool in collecting this type of data as well, as there is no official systematic data collection on causes of wildfires in Croatia

Furthermore, there were certain variables in this study which were not statistically significant factors in wildfire occurrence (e.g. road density, shrubland), despite being often mentioned during the interviews as one of the important factors in wildfire occurrence. This could be a consequence of data generalisation on a municipal level, but the additional buffer analysis in case of roads did not yield different results. This could be due to several different reasons - it is not clear if all types of roads are consistently mapped, or if the mapped roads are potentially inadequate for fire-fighting vehicles due to disrepair.

Finally, the continual of the observed socioeconomic processes together with projected climate change in the Mediterranean (higher temperatures, extended summer droughts) could lead to an increase wildfire frequency. At the moment, both the fire-fighters and the farmers in this research perceived the negative consequence of wildfires only in terms of material damage and loss of human lives. There was very little awareness (if any) of e.g. biodiversity issues, which could give rise to certain problems in the future, were balancing conflicting objectives with limited financial resources could mean less opportunity for prescribed burning as was the case of the protection of threatened woodland caribou in Canada (SHERry et al. 2019).

In order to tackle these complex issues, it is becoming increasingly necessary to introduce adequate management plans for abandoned agricultural land in the Mediterranean. Both fire-fighters 
and farmers in this research emphasised the need for an integrated, joint approach in fire-prevention, fire-fighting and planning of more resilient landscapes. Suggestions included supervised prescribed burning, composting agricultural waste instead of burning it, tackling unresolved property issues to name a few. One thing is certain, people are the main cause of this problem, but are also the main answer, and qualitative studies offer an opportunity to shed more light on the inherent complexities of human behaviour related to wildfire occurrence.

\section{Acknowledgments}

We gratefully acknowledge the commanders, shift managers and fire-fighters from the public fire brigade facilities from Šibenik, Knin, Drniš, Vodice and Split, and farmers form Šibenik-Knin and SplitDalmatia County for the interviews.

\section{References}

Adab, H.; Kanniah, K. D. and Solaimani, K. (2013): Modelling forest fire risk in the northeast of Iran using remote sensing and GIS techniques. In: Natural Hazards 65, 1723-1743. https://doi.org/10.1007/s11069-012-0450-8

Alcamo, J.; Moreno, J.; Nováky, B.; Bindi, M.; Corobov, R.; Devoy, R.; Giannakopoulos, C.; Martin, E.; Olesen, J. and Shvidenko, A. (2007): Europe. In: Parry, M.; Canziani, O.; Palutikof, J.; van der Linden, P. and Hanson, C. (eds): IPCC 2007: climate change: impacts, adaptation and vulnerability. Contribution of working group II to the fourth assessment report of the Intergovernmental Panel on Climate Change. Cambridge, 541-580.

Ashley, P. And Boyd, W. E. (2006): Quantitative and qualitative approaches to research in environmental management. In: Australasian Journal of Environmental Management 13 (2), 70-78. https://doi.org/10.1080/14486 563.2006.10648674

Azevedo, J. C.; Moreira, C.; Castro, J. P. and Loureiro C. (2011): Agriculture abandonment, land-use change and fire hazard in mountain landscapes in north-eastern Portugal. In: Li, C.; Lafortezza, R. and Chen, J. (eds.): Landscape ecology in forest management and conservation: challenges and solutions for global change. Heidelberg, Dordrecht, London, New York, 329-351. https:// doi.org/10.1007/978-3-642-12754-0_14

Barros, A. M. G. and Pereira, J. M. C. (2014): Wildfire selectivity for land cover type: does size matter? In: PLoS ONE 9 (1): e84760. https://doi.org/10.1371/journal. pone. 0084760
Bashari, H.; Naghipour, A. A.; Khajeddin, S. J.; Sangoony, H. and Tahmasebi, P. (2016): Risk of fire occurrence in arid and semi-arid ecosystems of Iran: an investigation using Bayesian belief networks. In: Environmental monitoring and assessment 188 (9), 531. https://doi. org/10.1007/s10661-016-5532-8

Bonebrake, T. C.; Guo, F.; Dingle, C.; Baker, D. M.; Kitching, R. L. and Ashton, L. A. (2019): Integrating proximal and horizon threats to biodiversity for conservation. In: Trends in Ecology and Evolution 34 (9), 781-788. https://doi.org/10.1016/j.tree.2019.04.001

Bonet, A. (2004): Secondary succession of semi-arid Mediterranean old-fields in south-eastern Spain: insights for conservation and restoration of degraded lands. In: Journal of Arid Environments 56, 213-233. https:// doi.org/10.1016/S0140-1963(03)00048-X

Brenkert-Smith, H. (2010): Building bridges to fight fire: the role of informal social interactions in six Colorado wildland-urban interface communities. In: International Journal of Wildland Fire 19 (6), 689-697. https://doi. org/10.1071/WF09063

Carmenta, R.; Parry, L.; Blackburn, A.; Vermeylen, S. and BARLOW, J. (2011): Understanding human-fire interactions in tropical forest regions: a case for interdisciplinary research across the natural and social sciences. In: Ecology and Society 16 (1): 53. https://doi. org/10.5751/ES-03950-160153

Carroll, M. S.; Cohn, P. J. and Blatner, K. A. (2004): Private and tribal forest landowners and fire risk: a twocounty case study in Washington State. In: Canadian Journal of Forest Research 34 (10), 2148-2158. https:/ / doi.org/10.1139/x04-085

Casado, M. A.; de Miguel, J. M.; Sterling, A.; Peco, B.; Galiano, E. F. Pineda, F. D.(1986): Production and spatial structure of Mediterranean pastures in different stages of ecological succession. In: Vegetatio 64, 75-86. https://doi.org/10.1007/BF00044783

Catry, F. X.; Rego, F. C. and Bacao F. L. (2009): Modelling and mapping wildfire ignition risk in Portugal. In: International Journal of Wildland Fire 18, 1-11. https://doi. org/10.1071/WF07123

Chapman, M.; Satterfield, T. and Chan, Kai M. A. (2019): When value conflicts are barriers: can relational values help explain farmer participation in conservation incentive programs? In: Land Use Policy 82, 464-475. https://doi.org/10.1016/j.landusepol.2018.11.017

Clarke, H; Tran, B; Boer, M. M; Price, O; Kenny, B. and Bradstock, R. (2019): Climate change effects on the frequency, seasonality and interannual variability of suitable prescribed burning weather conditions in south-eastern Australia. In: Agricultural and Forest Meteorology 271, 148-157. https://doi.org/10.1016/j.agrformet.2019.03.005 
Costa Freitas, M. B.; Xavier, A. and Fragoso, R. (2017): Integration of fire risk in a sustainable forest management model. In: Forests 8 (8): 270. https://doi.org/10.3390/ f8080270

Curt, T.; Borgniet, L. and Boulllon, C. (2013): Wildfire frequency varies with the size and shape of fuel types in south-eastern France: implications for environmental management. In: Journal of Environmental Management 117, 150-161. https://doi.org/10.1016/j.jenvman.2012.12.006

Cvitanović, M.; LuČev, I.; Fürst-Bjeliš, B.; Slavuj Borčić, L.; Horvat, S. and VAložIĆ, L. (2017): Analyzing postsocialist grassland conversion in a traditional agricultural landscape - Case study Croatia. In: Journal of Rural Studies 51, 53-63. https://doi.org/10.1016/j. jrurstud.2017.01.008

Del Hoyo, L. V.; Isabel, M. P. M. and Vega, F. J. M. (2011): Logistic regression models for human-caused wildfire risk estimation: analysing the effect of the spatial accuracy in fire occurrence data. In: European Journal of Forest Research, 130 (6), 983-996. https://doi. org/10.1007/s10342-011-0488-2

DGU (Državna Geodetska Uprava - Geoportal) (2015): http://geoportal.nipp.hr

Duane, A; Aquilue, N; Canelles, Q; Moran-Ordonez, A; de Caceres, M. and Brotons, L. (2019): Adapting prescribed burns to future climate change in Mediterranean landscapes. In: Science of the Total Environment 677, 68-83. https://doi.org/10.1016/j.scitotenv.2019.04.348

DZS (Državni Zavod Za Statistiku - Croatian Bureau of Statistics) (2015): https:/ / www.dzs.hr

Elia, M.; Lovreglio, R.; Ranieri, N. A.; Sanesi, G. and LaFORTEZZA, R. (2016): Cost-effectiveness of fuel removals in Mediterranean wildland-urban interfaces threatened by wildfires. In: Forests 7 (7): 149. https://doi. org/10.1016/j.ecolind.2014.08.034

Estes, B. L.; Knapp, E.; Skinner, C. N.; Miller, Y. D. and Preisler, H. K. (2017): Factors influencing fire severity under moderate burning conditions in the Klamath Mountains, northern California, USA. In: Ecosphere 8 (5), 1-20. https://doi.org/10.1002/ecs2.1794

European Environment Agency. https://www.eea.europa. $\mathrm{eu} /$ data-and-maps/indicators / forest-fire-danger-2/assessment (accessed on $18^{\text {th }}$ of February 2018)

Fischer, A. P. (2012): Identifying policy target groups with qualitative and quantitative methods: the case of wildfire risk on nonindustrial private forest lands. In: Forest Policy and Economics 25, 62-71. https://doi. org/10.1016/j.forpol.2012.08.008

Flatley, W. T.; Lafon, C. W. and Grissino-Mayer, H. D. (2011): Climatic and topographic controls on patterns of fire in the southern and central Appalachian. In: Landscape Ecology 26 (2), 195-209. https://doi. org/10.1007/s10980-010-9553-3
Gams, I. and Gabrovec, M. (1999): Land use and human impact in the Dinaric karst. In: International journal of Speleology 28 (1/4), 55-70. https://doi.org/10.5038/1827806X.28.1.4

Ganteaume, A.; Camia, A.; Jappiot, M.; San Miguel-Ayanz, J. and Long-Fournel, M. (2013): A review of the main driving factors of forest fire ignition over Europe. In: Environmental Management 51 (3), 651-662. https://doi. org/10.1007/s00267-012-9961-z

Giglio, L.; Randerson, J. T. and van der Werf, G. R. (2013): Analysis of daily, monthly, and annual burned area using the fourth-generation global fire emissions database (GFED4). In: Journal of Geophysical Research 188 (1), 317-328. https://doi.org/10.1002/jgrg.20042

Gonzalez, J. R.; Palahi, M.; Trasobares, A. and Pukkala, T. (2006): A fire probability model for forest stands in Catalonia (north-east Spain). In: Annals of Forest Science 63 (2), 169-176. https://doi.org/10.1051/ forest:2005109

Gudmundsson, L.; Rego, F. C.; Rocha, M. and Seneviratne, S. I. (2014): Predicting above normal wildfire activity in southern Europe as a function of meteorological drought. In: Environmental Research Letters 9: 084008. https://doi.org/10.1088/1748-9326/9/8/084008

Hodgson, I.D.; Redpath, S. M.; Fischer, A. and Young, J. (2019): When value conflicts are barriers: can relational values help explain farmer participation in conservation incentive programs? In: Journal of Environmental Management 231, 1065-1075. https://doi.org/10.1016/j.jenvman.2018.09.023

Jolibert, C, and Wesselink, A. (2012): Research impacts and impact on research in biodiversity conservation: the influence of stakeholder engagement. In: Environmental Science and Policy 22, 100-111. https://doi.org/10.1016/j. envsci.2012.06.012

Kalabokidis, K; Gatzojannis, S. and Galatsidas, S. (2002): Introducing wildfire into forest management planning: towards a conceptual approach. In: Forest Ecology and Management 158 (1-3), 41-50. https://doi.org/10.1016/ S0378-1127(00)00715-5

Kalabokidis, K. D.; Koutsias, N.; Konstantinidis, P. and VAsilakos, C. (2007): Multivariate analysis of landscape wildfire dynamics in a Mediterranean ecosystem of Greece. In: Area 39 (3), 392-402. https://doi. org/10.1111/j.1475-4762.2007.00756.x

KANGSEN SCAMELL, M. (2010): Qualitative environmental health research: an analysis of the literature, 1991-2008. In: Environmental Health Perspectives 118 (8), 11461154. https://doi.org/10.1289/ehp.0901762

Khabarov, N.; Krasovskit, A.; Obersteiner, M.; Swart, R.; Dosio, A.; San-Miguel-Ayanz, J.; Durrant, T.; Camia, A. and Migliavacca, M. (2016): Forest fires and adaption options in Europe. In: Regional Environmental Change 16 (1), 21-30. https://doi.org/10.1007/s10113-014-0621-0. 
Koksal, K; McLennan, J; Every, D. and Bearman, C. (2019): Australian wildland-urban interface householders' wildfire safety preparations: 'everyday life' project priorities and perceptions of wildfire risk. In: International Journal of Disaster Risk Reduction 33, 142-154. https://doi. org/10.1016/j.ijdrr.2018.09.017

Koutsias, N; Martinez-Fernandez, J. and Allgoewer, B. (2010): Do factors causing wildfires vary in space? Evidence from geographically weighted regression. In: GIScience \& Remote Sensing 47 (2), 221-240. https://doi. org/10.2747/1548-1603.47.2.221

Martinez-Fernandez, J.; Chuvieco, E. and Koutsias, N. (2013): Modelling long-term fire occurrence factors in Spain by accounting for local variations with geographically weighted regression. In: Natural Hazards and Earth System Sciences 13, 311-327. https://doi.org/10.5194/ nhess-13-311-2013

McGee, T. K. and Russell, S. (2003): "It's just a natural way of life..." an investigation of wildfire preparedness in rural Australia. In: Environmental Hazards 5, 1-12. https:/ / doi.org/10.1016/j.hazards.2003.04.001

MifKA, B. and VuČETIĆ, V. (2012): Vremenska analiza za vrijeme velikog šumskog požara na otoku Braču od 14. do 17. srpnja 2011. In: Vatrogastvo i upravljanje požarima 1 (3),13-25. https://hrcak.srce.hr/103617

Moreira, F.; Rego, F. C. and Ferreira, P. G. (2001): Temporal (1958-1995) pattern of change in a cultural landscape in north-western Portugal: implications for fire occurrence. In: Landscape Ecology 16, 557-567. https://doi. org/10.1023/A:1013130528470

Moreira, F.; Vaz, P.; Catry, F. and Silva, J. S. (2009): Regional variations in wildfire susceptibility of land-cover types in Portugal: implications for landscape management to minimize fire hazard. In: International Journal of Wildland Fire 18, 563-574. https://doi.org/10.1071/WF07098

Moulllot, F.; Ratte, J. P.; Joffre, R.; Moreno, J. M. and RamBAL, S. (2003): Some determinants of the spatio-temporal fire cycle in a Mediterranean landscape (Corsica, France). In: Landscape Ecology 18 (7), 665-674. https://doi. org/10.1023/B:LAND.0000004182.22525.a9

Müller, M. M.; VaciK, H.; Diendorfer, G.; Arpaci, A.; Formayer, H. and Gossov, H. (2013): Analysis of lightning-induced forest fires in Austria. In: Theoretical and Applied Climatology 111 (1-2), 183-193. https://doi. org/10.1007/s00704-012-0653-7

NASA/METI/AIST/Japan Spacesystems, and U.S./Japan ASTER Science Team. ASTER Global Digital Elevation Model V003. 2019, distributed by NASA EOSDIS Land Processes DAAC, https://doi.org/10.5067/ASTER/ ASTGTM.003.

Nunes, A. N. (2012): Regional variability and driving forces behind forest fires in Portugal an overview of the last three decades (1980-2009). In: Applied Geogra- phy 34, 576-586. https://doi.org/10.1016/j.apgeog.2012.03.002

Nunes, A. N.; Lourenco, L. and Meira Castro, A. C. (2016): Exploring spatial patterns and drivers of forest fires in Portugal (1980-2014). In: Science of the Total Environment 573, 1190-1202. https://doi.org/10.1016/j.scitotenv.2016.03.121

Oliveira, S.; Moreira, F.; Boca, R.; San-Miguel-Ayanz, J. and Pereira, J. M. C. (2013): Assessment of fire selectivity in relation to land cover and topography: a comparison between Southern European countries. In: International Journal of Wildland Fire 23 (5), 620-630. https://doi. org/10.1071/WF12053

Oliveira, S.; Oehler, F.; San-Miguel-Ayanz, J.; Camia, A. and Pereira, J. M. C. (2012): Modelling spatial patterns of fire occurrence in Mediterranean Europe using multiple regression and random forest. In: Forest Ecology and Management 275, 117-129. https://doi.org/10.1016/j. foreco.2012.03.003

PAHL, S. and WYLES, K. J. (2017): The human dimension: how social and behavioural research methods can help address microplastics in the environment. In: Analytical Methods 9, 1404-1411. https://doi.org/10.1039/C6AY02647H

Pavlek, K.; Bišćević, F.; Furčić, P.; GrĐan, A.; Gugić, V.; Malešić, N.; Moharić, P.; Vragović, V.; Fuerst-Bjeliš, B. and Cvitanović, M. (2016): Spatial patterns and drivers of fire occurrence in a Mediterranean environment: a case study of southern Croatia. In: Geografisk TidsskriftDanish Journal of Geography 117 (1), 22-35. https:// doi.org/10.1080/00167223.2016.1266272

PiCHLER, T. (2008): Environment protection and fire. In: Safety 5 (4), 399-414. https:/ / hrcak.srce.hr/30593

Rego, F.; Rigolot, E.; Fernandes, P.; Montiel, C. and Silva, J. S. (2010): Towards integrated fire management. Proceedings of the Conference on Protection of Forests, La Granja Valsaín, Spain, 6-7 April 2010.

Rios-Pena, L.; Kneib, T.; Cardarso-Suarez, C. and MareyPerez, M. (2016): Predicting the occurrence of wildfires with binary structured additive regression models. In: Journal of Environmental Management 187, 154-165. https://doi.org/10.1016/j.jenvman.2016.11.044

Rodrigues, M.; De la Riva, J. and Fotheringham, S. (2014): Modeling the spatial variation of the explanatory factors of human-caused wildfires in Spain using geographically weighted logistic regression. In: Applied Geography 48, 52-63. https://doi.org/10.1016/j.apgeog.2014.01.011

Romero-Calcerrada, R. and Perry, G. L. W. (2004): The role of land abandonment in landscape dynamics in the SPA 'Encinares del rio Alberche y Cofio, Central Spain, 19841999. In: Landscape and Urban Planning 66, 217-232. https://doi.org/10.1016/S0169-2046(03)00112-9

Rosavec, R.; ŠPAnjol, Ž. and BAKŠIĆ, N. (2012): Forest fires as an ecological and landscape factor in the Dalmatian 
hinterland. In: Firefighting and management 2 (1), 5164. https://hrcak.srce.hr/103620

Sadasivuni, R; Cooke, W. H. and Bhushan, S. (2013): Wildfire risk prediction in southeastern Mississippi using population interaction. In: Ecological Modelling 251, 297-306. https://doi.org/10.1016/j.ecolmodel.2012.12.024

Sherry, J; Neale T; McGee T. K. and Sharpe M. (2019): Rethinking the maps: a case study of knowledge incorporation in Canadian wildfire risk management and planning. In: Journal of Environmental Management 234, 494502. https://doi.org/10.1016/j.jenvman.2018.12.116

Tomašević, I. and Vučetić, V. (2014): Ocjena požarne sezone 2013. godine i usporedba s požarnom sezonom 2012. godine. In: Vatrogastvo i upravljanje požarima 4, 19-35.

Tsoi, O. M. (2009): The natural factors that are responsible for forest fires in the southern Far East. In: Geography and Natural Resources 30 (2), 136-140. https:/ / doi. org/10.1016/j.gnr.2009.06.008

Turco, M.; Bedia, J.; Di Liberto, F.; Fiorucci, P.; von Hardenberg, K.; Koutsias, N.; Llasat, M. C.; XystraKIS, F. and Provenzale, A. (2016): Decreasing fires in Mediterranean Europe. In: PLoS ONE 11 (3). https:// doi.org/10.1371/journal.pone.0150663

Vaiciulyte, S.; Galea, E. R.; Veeraswamy, A. and Hulse, L. M. (2019). Island vulnerability and resilience to wildfires: a case study of Corsica. In: International Journal of Disaster Risk Reduction 40. https://doi.org/10.1016/j. ijdrr.2019.101272

Villar, L.; Gómez, I.; Martínez-Vega, J.; Echavarría, P.; Riaño, D. and Martín, M. P. (2016): Multitemporal modelling of socio-economic wildfire drivers in Central Spain between the 1980s and the 2000s: comparing generalized linear models to machine learning algorithms. In: PLoS ONE 11 (8). https:/ / doi.org/10.1371/journal. pone.0161344

WING, S. (2003): Objectivity and ethics in environmental health science. In: Environ Health Perspect. 111, 18091818. https://doi.org/10.1289/ehp.6200

Woodroffe, R.; Thirgood, S. and Rabinowitz, A. (2005): People and wildlife, conflict or co-existence? Cambridge. https://doi.org/10.1017/CBO9780511614774

Ye, J.; Wu, M.; Deng, Z.; Xu, S.; Zhou, R.; and Clarke, K. C. (2017): Modeling the spatial patterns of human wildfire ignition in Yunnan province, China. In: Applied Geography 89, 150-162. https://doi.org/10.1016/j. apgeog.2017.09.012

Yocom, L. L.; Jenness, J.; Fulé, P. Z.; and Thode, A. E. (2019): Previous fires and roads limit wildfire growth in Arizona and New Mexico, U.S.A. In: Forest Ecology and Management 449, 117440. https://doi.org/10.1016/j. foreco.2019.06.037

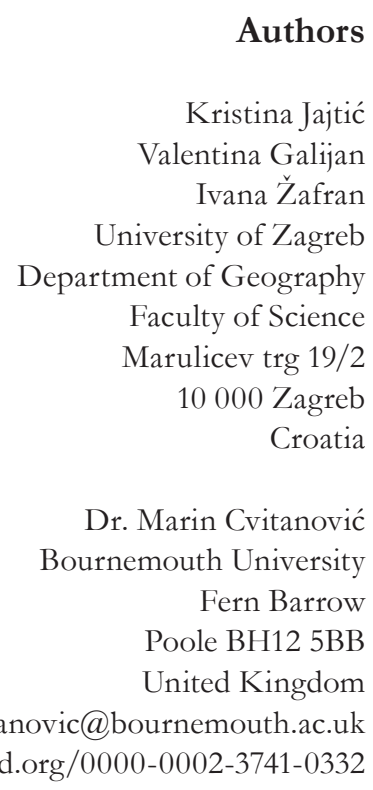

Authors

Jajtić lentina Galijan fran Faculty of Science arulicev trg 19/2 roatia

Dr. Marin Cvitanović Fern Barrow Poole BH12 5BB United Kingdom mcvitanovic@bournemouth.ac.uk http://orcid.org/0000-0002-3741-0332 